\title{
Wage Determination In The Public Sector
}

\author{
Joseph N. Heiney, Elmhurst College, USA
}

\begin{abstract}
As the economy continues to recover from the recent recession of 2008-2009, there has been much discussion of the related issues of increases in federal, state, and local budget deficits and debt. A major element of that discussion concerns public employee salaries and benefits, including underfunded pension benefits. This paper involves the development of a theoretical model for the determination of wages and salaries in the public sector which has implications for these current issues.
\end{abstract}

Keywords: Public Sector; Wage Determination

\section{INTRODUCTION}

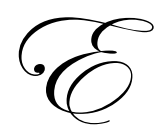

conomists have frequently discussed the differences between the economic marketplace and the political market in various contexts. It has been argued that the substitution of political decision making for economic decision making in the production process removes incentives for cost minimization and results in less efficient production.

Much attention has focused on a positive economic analysis of the political process involved in government regulation, first suggested by Stigler (1971) and extended by Peltzman (1976), both of which built on the previous work of Downs (1957) and Olson (1965). These discussions center on the notion of interest groups seeking favorable treatment from a regulatory agency. At the simplest level, the groups are consumers and producers; and the question is which group will be relatively more successful in increasing its wealth through the political process. Another group whose influence might be considered is the employees of the regulated firms. A case in which employees are more directly an interest group in the political process is in public employment. The wages of public employees are directly a political decision, and one may ask whether, and to what extent, employees can influence their wages through the political process.

There can be little doubt of the attempt of public employee groups to influence their welfare through political activity. Publications of state educational associations include information on candidates' voting records on educational issues and urge the support of candidates sympathetic to teachers' positions. The National Education Association strongly supported the creation of a separate Department of Education, which, some observers argue, largely serves the function of representing educational interests. At the state and national levels, employee groups seek to influence public policies concerning the rights of public employees to organize, engage in collective bargaining, and strike.

This paper applies the economic theory of political behavior to the public sector labor market. It will be argued that the political support maximization model of political behavior is a useful framework within which to view the determination of public employees' wages. The theoretical model asserts that some government agency, such as a school board, responsible for the provision of a public service has the power to tax constituents within its jurisdiction and to set wages for its employees. Members of the government agency attempt to maximize their political support. Support from citizens depends on the taxes imposed to finance a given level of service and the uninterrupted provision of the service. Employees offer support in return for higher wages and may attempt to influence support from citizens by threatening disruption of the service. The agency sets wages and taxes so as to 
maximize its political support from constituents and employees. The model suggests that the relative success of employees or constituents in this political process depends on the characteristics of the community.

\section{LABOR IN THE PUBLIC SECTOR}

Many previous studies have examined a variety of issues concerning labor in the public sector. Ashenfelter (1971) and Ehrenberg (1973b) examined the effect of the International Association of Firefighters (IAFF) on the wages of firemen. Ashenfelter (1971) notes the political activity of the union and then proceeds, in the manner suggested by Lewis (1963), to determine the effect of the IAFF. Ehrenberg (1973b) extends Ashenfelter's analysis within a supply and demand framework by adding variables including whether fire department services are administered by a city manager, fire commissioner, or city council. This reflects, at least partially, the political consideration that a professional manager may be more able in the wage negotiation process and less subject to political pressures.

Studies which examine the appropriate model within which to view public sector wage determination include Ehrenberg (1973a) and Ashenfelter and Ehrenberg (1975) which derive their results from a utilitymaximizing model in which utility is a function of publicly and privately produced goods and services. Niskenen (1971) develops a theory of the output and pricing decisions of a government bureau providing a public service within a representative government. Courant, Gramlich, and Rubinfeld (1979) review the literature which argues that the public sector will grow due to the influence of public employees in the political process and provide a model of public employment and wage determination, including both the political and economic power of government employees and the limitations on that power from private sector mobility. Anable (1974) proposes a model of wage determination in public employment based on a range theory of wage negotiations. Barr and Davis (1966) propose a theory of local government expenditures incorporating political considerations following Downs (1957) ideas which presumes that candidates who propose a platform of expenditures equal to that level desired by the median voter will be elected.

\section{A MODEL OF PUBLIC SECTOR WAGE DETERMINATION}

These propositions about the political support offered by employees and citizens can be formalized in a model of political support maximization by the governmental agency. It is argued previously that employees' support will increase in response to higher wages offered by the agency. Then agency's perception of the probability that an employee will support it, $\mathrm{p}_{1}$, can be described by a function,

$\mathrm{p}_{1}=\mathrm{p}_{1}(\mathrm{w})$, with $\partial \mathrm{p}_{1} / \partial \mathrm{w}>0$ and $\partial^{2} \mathrm{p}_{1} / \partial \mathrm{w}^{2}<0$.

The agency is more uncertain of citizens' positions, that is, uncertain about the amount of support expected from citizens in response to any proposed tax increase to finance higher wages. This uncertainty can be described by a function showing the agency's perception of the probability, $\mathrm{p}_{2}$, that a citizen will vote favorably at various levels of taxes with other factors which influence citizens' support, such as uninterrupted provision of the service, held constant. If $\mathrm{P}$ is the base of the tax on each citizen and $\mathrm{t}$ is the tax rate,

$\mathrm{p}_{2}=\mathrm{p}_{2}(\mathrm{tP})$, with $\partial \mathrm{p}_{2} / \partial(\mathrm{tP})<0$ and $\partial^{2} \mathrm{p}_{2} / \partial(\mathrm{tP})^{2}<0$.

Support from citizens depends not only on the level of taxes but also on the uninterrupted provision of the service. Disruption of the service will reduce support from citizens, other factors held constant. Thus, employees can influence political support by threatening to disrupt service is a wage increase is not granted. Service can be disrupted in various ways and to various degrees. For simplicity, consider disruption in the form of a strike. The probability that employees will strike is lower, the higher the wage the agency offers. Let $\mathrm{p}_{\mathrm{d}}$ indicate the probability of disruption, where

$\mathrm{p}_{\mathrm{d}}=\mathrm{p}_{\mathrm{d}}(\mathrm{w})$, with $\partial \mathrm{p}_{\mathrm{d}} / \partial \mathrm{w}<0$ and $\partial^{2} \mathrm{p}_{\mathrm{d}} / \partial \mathrm{w}^{2}>0$. 
The amount of disruption expected to result at different wage levels depends not only on the probability that disruption will occur but also on the percentage of the population utilizing the service, that is, the percentage for which a strike will be disruptive, times the inconvenience to each. Let $\mathrm{n}_{\mathrm{d}}$ indicate the number of citizens using the service; $\mathrm{n}_{2}$, the total population; and $\mathrm{d}$, the inconvenience to each person using the service if service is interrupted. Then, expected disruption per capita is given by

$E(D)=p_{d}\left(n_{d} / n_{2}\right) d$.

Offering a higher wage pays political rewards in terms of lower expected disruption, but the effect of a higher wage offer depends not only on how much the probability of disruption falls but also on $\mathrm{n}_{\mathrm{d}} / \mathrm{n}_{2}$ and $\mathrm{d}$, that is,

$\partial \mathrm{E}(\mathrm{D}) / \partial \mathrm{w}=\left(\mathrm{n}_{\mathrm{d}} / \mathrm{n}_{2}\right) \mathrm{d}\left(\partial \mathrm{p}_{\mathrm{d}} / \partial \mathrm{w}\right)$.

The payoff from a given increase in $w$ will be smaller if $n_{d} / n_{2}$ or $d$ is smaller, given

$\partial \mathrm{p}_{\mathrm{d}} / \partial \mathrm{w}$.

So, the probability that a citizen will support the agency is a function of the level of taxes imposed by the agency and the expected disruption which will result from the agency's actions.

$\mathrm{p}_{2}=\mathrm{p}_{2}(\mathrm{tP}, \mathrm{E}(\mathrm{D}))$, with $\partial \mathrm{p}_{2} / \partial(\mathrm{tP})<0$ and $\partial^{2} \mathrm{p}_{2} / \partial(\mathrm{tP})^{2}<0$

$$
\partial \mathrm{p}_{2} / \partial \mathrm{E}(\mathrm{D})<0 \text { and } \partial^{2} \mathrm{p}_{2} / \partial \mathrm{E}(\mathrm{D})^{2}<0
$$

The agency's objective is to set the wage paid to employees and the tax rate imposed on citizens so as to maximize political support. For simplicity, assume as usual that different forms of support can be transformed into the one dimensional measure votes, $V$. If the number of employees is $n_{1}$ and the number of citizens is $n_{2}$, then expected votes from employees, $V_{1}$, is $n_{1} p_{1}$; and expected votes from citizens, $V_{2}$, is $n_{2} p_{2}$.

The agency seeks to maximixe the function,

$\mathrm{V}=\mathrm{V}_{1}+\mathrm{V}_{2}=\mathrm{n}_{1} \mathrm{p}_{1}(\mathrm{w})+\mathrm{n}_{2} \mathrm{p}_{2}(\mathrm{tP}, \mathrm{E}(\mathrm{D}))$

In doing so the agency operates under a budget constraint that expenditures must equal receipts,

$\mathrm{n}_{2} \mathrm{tP}+\mathrm{O}=\mathrm{wn}_{1}+\mathrm{p}_{\mathrm{x}} \mathrm{X}$

where $\mathrm{O}$ is revenue from sources other than taxes on citizens, $\mathrm{p}_{\mathrm{x}}$ is the price of nonlabor inputs, and $\mathrm{X}$ is the quantity of nonlabor inputs.

If the agency cannot substitute nonlabor for labor resources in response to an increase in w and if other sources of revenue are fixed, then the change in $t$ necessary to finance a one unit increase in $w$ is

$\partial \mathrm{t} / \partial \mathrm{w}=\mathrm{n}_{1} / \mathrm{n}_{2} \mathrm{P}$.

A one dollar increase in $w$ will cost $n_{1}$ dollars and require an increase in the tax rate of $n_{1} / n_{2} P$.

The agency sets $\mathrm{w}$ and $\mathrm{t}$ to maximize the Lagrangian,

$\mathrm{L}=\mathrm{n}_{1} \mathrm{p}_{1}(\mathrm{w})+\mathrm{n}_{2} \mathrm{p}_{2}\left(\mathrm{tP}, \mathrm{p}_{\mathrm{d}}(\mathrm{w})\left(\mathrm{n}_{\mathrm{d}} / \mathrm{n}_{2}\right) \mathrm{d}\right)+\lambda\left(\mathrm{n}_{2} \mathrm{tP}+\mathrm{O}-\mathrm{wn}_{1}-\mathrm{p}_{\mathrm{x}} \mathrm{X}\right)$.

The first order conditions for a maximum are

$\partial \mathrm{L} / \partial \mathrm{w}=\mathrm{n}_{1} \partial \mathrm{p}_{1} / \partial \mathrm{w}+\mathrm{n}_{\mathrm{d}} \partial \mathrm{p}_{2} / \partial \mathrm{E}(\mathrm{D}) \mathrm{d} \partial \mathrm{p}_{\mathrm{d}} / \partial \mathrm{w}-\lambda \mathrm{n}_{1}=0$ 
$\partial \mathrm{L} / \partial \mathrm{t}=\mathrm{n}_{2} \partial \mathrm{p}_{2} / \partial(\mathrm{tP}) \mathrm{P}+\lambda \mathrm{n}_{2} \mathrm{P}=0$

$\partial \mathrm{L} / \partial \lambda=\mathrm{n}_{2} \mathrm{tP}+\mathrm{O}-\mathrm{wn}_{1}-\mathrm{p}_{\mathrm{x}} \mathrm{X}=0$

The second order conditions for a maximum are fulfilled, given the signs of the second ofer partial derivatives specified above.

From expression (11),

$\mathrm{n}_{1} \partial \mathrm{p}_{1} / \partial \mathrm{w}+\mathrm{n}_{\mathrm{d}} \partial \mathrm{p}_{2} / \partial \mathrm{E}(\mathrm{D}) \mathrm{d} \partial \mathrm{p}_{\mathrm{d}} / \partial \mathrm{w}=\lambda \mathrm{n}_{1}$

The left-hand side of (14) is the marginal vote product of an increase in w. The first term indicates the number of additional votes from employees which results from a one dollar increase in w. The second term is the number of additional votes from citizens forthcoming from the fact that a one dollar increase in $\mathrm{w}$ reduces expected disruption. The right-hand side of (14) is the marginal vote cost of an increase in w. A one dollar increase in w will $\operatorname{cost} n_{1}$ dollars, and $\lambda$ is the marginal vote opportunity cost of public expenditures. Expression (14), therefore, indicates that the wage paid to employees will be set so that the marginal vote product equals the marginal vote cost, that is, the agenchy will increase wages until the additional votes generated by the last dollar increase in $\mathrm{w}$ are equal to the additional votes lost by spending the last dollar on an increase in w instead of putting it to some other vote generating use, such as reducing taxes.

From expression (12),

$-\mathrm{n}_{2} \partial \mathrm{p}_{2} / \partial(\mathrm{tP}) \mathrm{P}=\lambda \mathrm{n}_{2} \mathrm{P}$

Here the left-hand side is the marginal vote product of a decrease in $t$, that is, the increase in the number of citizens' votes which results from a one unit decrease in $t$. The right-hand side is the marginal vote cost of a decrease in $t$, that is, the decrease in votes which results from a one unit decrease in $t$, since a one unit decrease in $t$ will reduce tax revenue by $\mathrm{n}_{2} \mathrm{P}$ dollars and $\lambda$ is the vote opportunity cost of one dollar. Thus, the agency will set $t$ so that the number of votes gained from the last unit decrease in $t$ is equal to the number of votes lost by not putting the forgone tax reveine to some other vote generating use, such as increasing wages.

Expressions (11) and (12) can be combined, giving

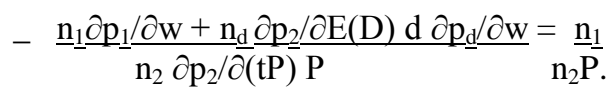

This is the familiar form of the maximizing condition, that is, the ratio of the marginal vote products should equal the ratio of the marginal vote costs.

Consider the government employer trading increased votes from employees by raising wages for decreased votes from citizens by raising taxes, so that total votes remain constant. The rate at which this tradeoff can be made is given by the expression on the left-hand side of (16). All combinations of $w$ and $t$ which generate a given level of votes describe an isovote curve with slope, dw/dt, given by the left-hand side of (16). Given the signs of the first and second order derivatives specified previously, these isovote curves will be increasing at a decreasing rate, with $\mathrm{V}$ increasing in a southeasterly direction.

The employers budget constraint from (8) can be written as

$\mathrm{t}=\underline{\underline{\mathrm{p}_{2}}} \underline{\underline{\mathrm{X}}-\mathrm{O}}+\underset{\mathrm{n}_{2} \mathrm{P}}{\mathrm{n}_{2} \mathrm{P}} \quad \mathrm{w}$, with $\partial \mathrm{t} / \partial \mathrm{w}=\mathrm{n}_{1} / \mathrm{n}_{2} \mathrm{P}$

This is the right-hand side of (16) and indicates the rate at which $t$ must rise to finance increases in w. 
The vote maximizing equilibrium in (16) appears graphically as the familiar tangency of the constraint with an isovote curve.

\section{CONCLUSION}

This is an explicit model of the political process of public employee wage determination, which suggests specifically the ways employees and citizens can influence wages and taxes and has implications for the circumstances under which each group will be relatively more successful.

\section{AUTHOR INFORMATION}

Joseph N. Heiney received his Ph.D. in Economics from the University of Chicago. He is currently Professor of Economics at Elmhurst College in Elmhurst, Illinois. Previously he served as the Director of the Center for Business and Economics and Coleman Foundation Distinguished Chair at Elmhurst College. His recent research has been concerned with the U.S. banking industry and labor in the public sector. Email: josephh@elmhurst.edu

\section{REFERENCES}

1. Anable, James E. A Theory of Wage Determination in Public Employment. Quarterly Review of Economics and Business 14 (Winter 1974): 43-58.

2. Ashenfelter, Orley. The Effects of Unionization on Wages in the Public Sector: The Case of Firefighters. Industrial and Labor Relations Review 24 (January 1971): 191-202.

3. Ashenfelter, Orley and Ehrenberg, Ronald G. The Demand for Labor in the Public Sector. In Labor in the Public and Nonprofit Sectors. Edited by Danial S. Hameremesh. Princeton, N.J.: Princeton University Press, 1975.

4. Barr, James L., and Davis, Otto A. An Elementary Political and Economic Theory of Local Governments. Southern Economic Journal 33 (October 1966): 149-65.

5. Courant, Paul N., Gramlich, Edward M., and Rubinfeld, Daniel L. Public Employee Market Power and the Level of Government Spending. American Economic Review 69 (December 1979): 806-17.

6. $\quad$ Downs, Anthony. An Economic Theory of Democracy. New York: Harper and Row, 1957.

7. Ehrenberg, Ronald G. The Demand for State and Local Government Employees. American Economic Review 63 (June 1973): 366-79

8. Lewis, H. G. Unionism and Relative Wages in the United States. Chicago: University of Chicago Press, 1963.

9. Municipal Government Structure, Unionization, and the Wages of Firefighters. Industrial and Labor Relations Review 27 (October 1973): 36-48.

10. Niskanen, William A. Bureaucracy and Representative Government. Chicago: Aldine, 1971.

11. Olson, Mancur. The Logic of Collective Action: Public Goods and the Theory of Groups. Cambridge, Mass.: Harvard University Press, 1965.

12. Peltzman, Sam. Toward a More General Theory of Regulation. Journal of Law and Economics 19 (August 1976): 211-40.

13. Stigler, George J. The Theory of Economic Regulation. Bell Journal of Economics and Management Science 2 (Spring 1971): 3-21. 
Journal of Business \& Economics Research - November 2011

\section{NOTES}

